\title{
ПЕДАГОГИКА
}

PEDAGOGIGS

УДК 378.11

DOI 10.18413/2075-4574-2019-38-3-428-438

\section{TECHNOLOGY OF FORMING THE CULTURE OF TOLERANCE IN EDUCATIONAL INSTITUTIONS OF SECONDARY VOCATIONAL AND HIGHER EDUCATION}

\section{ТЕХНОЛОГИЯ ФОРМИРОВАНИЯ КУЛЬТУРЫ ТОЛЕРАНТНОСТИ В ОБРАЗОВАТЕЛЬНЫХ ОРГАНИЗАЦИЯХ СРЕДНЕГО ПРОФЕССИОНАЛЬНОГО И ВЫСШЕГО ОБРАЗОВАНИЯ}

\author{
С.А. Вербицкая' ${ }^{1)}$, С.В. Анохина ${ }^{2)}$ \\ S.A. Verbitskaya ${ }^{1)}$, S.V. Anokhina ${ }^{2)}$ \\ ${ }^{1)}$ Белгородский государственный аграрный университет им. В.Я. Горина, \\ 308503, Россия, Белгородская обл., Белгородский р-н, п. Майский, ул. Вавилова, 1 \\ ${ }^{2)}$ Белгородский государственный национальный исследовательский университет, \\ 308007, Россия, г. Белгород, ул. Студенческая, 14 \\ ${ }^{1)}$ Belgorod State Agricultural University named after V. Gorin, \\ 1 Vavilov St, Mayskiy, Belgorod region, 308503, Russia \\ Belgorod National Research University, \\ 14 Studencheskaya St, Belgorod, 308007, Russia \\ E-mail: s_verbitskaya@mail.ru, Anohina_s@bsu.edu.ru
}

\begin{abstract}
The introduction of the technology of forming the culture of tolerance in educational institutions of secondary vocational and higher education is considered. This process includes several stages: planning and modeling phase, procedural and organizing phase, result and analytical phase. Each stage of the technology of forming the culture of tolerance contains the purpose and content, the actions of the mentor and students, the field of their interaction, the result of the interaction of participants. A number of pedagogical conditions contributing to the formation of the culture of tolerance in students in educational institutions is given. This technology can be included in the educational plan of the mentor of the students' group in educational institutions of secondary vocational and higher education. Mentors of students' groups, teachers can use separate exercises and classes in the structure of curatorial lessons. It can be used in the areas with high interethnic tension and instability. Conducting training sessions and curatorial lessons, it is desirable to take into account the psychological and pedagogical age characteristics of the participants, their cultural identity and religion. The organization of special training for mentors at the experimental «School for the mentor of the students' group» is an indicator of the systematic educational activities of the mentor on formation of the culture of tolerance in the educational process and represents the realization of such pedagogical condition as ensuring the unity of the theoretical and technological training of mentors to formation of the culture of tolerance in students. 117 students from 6 academic groups of the Belgorod State Agricultural University named after V. Gorin took part in the experiment on the formation of the culture of tolerance in the educational activities of the mentor of the students' group.
\end{abstract}




\section{Аннотация}

Процесс формирования культуры толерантности предполагает систематическую, целенаправленную работу с кураторами и студенческими группами. Он включает несколько этапов: проектно-моделирующий, процессуально-организационный, итогово-аналитический. Каждый из этих этапов состоит из цели и содержания, действия куратора и студентов, поле их взаимодействия, результат взаимодействия участников. Данная технология может быть включена в план воспитательной работы куратора студенческой группы в образовательных организациях среднего профессионального и высшего образования. Кураторы студенческих групп, педагоги могут использовать отдельные упражнения и занятия в структуре кураторского часа. Технология формирования культуры толерантности может быть использована, в том числе, в областях с высокой межэтнической напряженностью и нестабильностью. Проводя тренинговые занятия и кураторские часы, педагогу необходимо учитывать психолого-педагогические возрастные особенности участников, их культурную принадлежность и вероисповедание. Организация специального обучения кураторов в экспериментальной «Школе куратора студенческой группы» является показателем системной воспитательной деятельности куратора по формированию культуры толерантности в образовательном процессе и представляет собой реализацию такого педагогического условия, как обеспечение единства теоретической и технологической подготовки кураторов к формированию культуры толерантности у студентов в образовательных организациях среднего профессионального и высшего образования. В эксперименте приняли участие 117 студентов из 6 академических групп Белгородского государственного аграрного университета имени В.Я. Горина.

Keywords: development of the culture of tolerance, mentor, «School for the mentor of the students' group», training of tolerance.

Ключевые слова: формирование культуры толерантности, куратор, «Школа куратора студенческой группы», тренинг толерантности.

\section{Introduction}

The use of modern educational technologies in the humanitarian (liberal) education is aimed at achieving an important goal - the forming of tolerance of future professional, researcher, and intellectual [Selevko, 2005; Kolechenko, 2006]. The formation of social values entails the development in a person of such qualities as willingness to cooperate, dignity, respect, which, in turn, contribute to the positive interaction of people [Potapenko, 2016]. According to modern philosophers, Lektorsky V.A. et al., tolerance is a moral quality of an individual, a principle (condition) of relationships between people, characterized by tolerance, understanding, and a desire for dialogue with the Different [Lektorsky, 1997, p. 14-18]. Thus, tolerance is a socially significant value of the individual.

Technology of forming the culture of tolerance in educational institutions of secondary vocational and higher education - it is a psychological and pedagogical technology, as it presents logically related specific procedures, methods and techniques directed at positive changes in personal characteristics, such as accepting the ideas of non-violence, adopting the Different, emotional stability, self-control, patience, developing of skills in interpersonal, social, intercultural, professional interaction.

The pedagogical conditions providing the forming of the culture of tolerance in students of educational institutions include: 1) systematic educational activities of the mentor of students' groups on formation of the culture of tolerance in the educational process of the educational institution; 2) ensuring the unity of the theoretical and technological training of mentors to formation of the culture of tolerance in students; 3) the establishment of tolerance-oriented educational environment in the students' group; 4) the subject-subjectival interaction of the mentor and students.

The implementation of these conditions was realized during the introduction of technology of forming the culture of tolerance in students in the activities of the mentor of the students' group. 


\section{Main part \\ Description and analysis of the research material}

117 students from 6 academic groups of the agronomy faculty, the faculty of veterinary medicine and the faculty of secondary vocational education of the Belgorod State Agricultural University named after V. Gorin took part in the «forming» experiment on the formation of the culture of tolerance in the educational activities of the mentor of the students' group. Three groups were experimental and three groups were control. One group of each department was experimental, the other one was control. The experiment suggested the implementation of the structural-dynamic model of forming the culture of tolerance in students in the activities of the mentor of the students' group.

The ascertaining experiment, carried out in two universities: Belgorod State Agricultural University named after V. Gorin and the Kursk State Agricultural Academy named after Professor I. Ivanov, which included the participation of 482 full-time students and 105 mentors of students' groups, provided the necessary diagnostic information of understanding the tolerant relations and their distinctive features, and revealed insufficient understanding of tolerance by the students of these educational institutions.

Since the ascertaining experiment revealed insufficient understanding by mentors of the importance of work on forming the culture of tolerance in students, the purpose of the experimental work was to realize the unity of theoretical and technological training of mentors to formation the culture of tolerance in students.

Guided by the positive experience of the Department of Pedagogy of the Faculty of Psychology of the Belgorod National Research University, we suggested that it would be advisable to increase the level of psychological and pedagogical training of mentors of students' groups, as well as carry out parallel work with mentors and supervised groups towards the formation of the culture of tolerance.

It was decided to create an experimental «School for the mentor of the students' group» in the Belgorod State Agricultural University named after V. Gorin, similar to the School of the mentor of the Belgorod National Research University, where theoretical and technological training of mentors for productive interaction with students would be carried out at the training seminars for the mentors. We have worked out a training-thematic plan, according to which mentors' seminars were held once a month.

The seminars were devoted to the rights, duties, main goals and objectives, activities, mentor functions. Forms and types of planning were considered, including individual and collective planning, preparation and planning of educational activities. The age characteristics of students, their adaptation to students' life, as well as the problems of further developing the professional maturity of future specialist were discussed [Isaev, Eroshenkova, 2010]. A number of lessons was devoted to the goals and objectives of studying the student's personality, personality study programs, the general culture of the individual, the culture of tolerance, patience, acceptance, adoption, leniency, tolerance. The role of the mentor in developing the culture of tolerance in students was emphasized, the mentor's readiness to forming the culture of tolerance in students was considered, and the relationship of the culture of tolerance of future specialists and the pedagogical culture of the mentor. Special attention was paid to the pedagogical conditions that influence the development of the culture of tolerance in the educational activities of the mentor, the forms and methods of interaction the mentor and students, and the stages of the technology of forming the culture of tolerance in the activities of the mentor were studied and considered.

In the process of training of the mentors, interviews, surveys, questionnaires were conducted to check how effectively the «School of the mentor» functions. The main task at this stage was to increase the culture of tolerance level of the mentors and to master the components of the technology of forming the culture of tolerance in students. 
The organization of special training for mentors at the experimental «School for the mentor of the students' group» was an indicator of the systematic educational activities of the mentor on formation of the culture of tolerance in the educational process and represented the realization of such pedagogical condition as ensuring the unity of the theoretical and technological training of mentors to formation of the culture of tolerance in students.

The next goal of our research was to ensure the sequence and interdependence of the stages of the technology of forming the culture of tolerance in students in the activities of the mentor of the students' group. The process of formation assumed systematic, purposeful work with mentors and students' groups in the formation of the culture of tolerance. This complex process goes through several stages in its development: planning and modeling phase, procedural and organizing phase, result and analytical phase [Verbitskaya, 2019].

Each stage of the technology of forming the culture of tolerance contains the purpose and content, the actions of the mentor and students, the field of their interaction, the result of the interaction.

The first stage of forming the culture of tolerance in students is a planning and modeling stage, the purpose of which was organizing the diagnosis of the degree of tolerance and the actualization of students' ideological (axiological) attitudes.

At this stage, the mentor studied the students of his group thoroughly in order to determine their own ideological views.

The stage also included the study by students of their personal characteristics and qualities, the determination by them independently or with the help of a group of their level of tolerance, which is of great importance when they are included in adulthood, the formation of their identity and the development of various social roles. Thus, the foundation for the choice of peace to be made by future generations, the peaceful coexistence of humanity, and not conflict and military action is created [Bondarevskaja, 2010].

At this stage, the technologies and methods that acquaint the student with himself were effective. Such techniques form the need to know oneself: to determine whether he (the student) is tolerant or intolerant, whether he is focused on himself, whether the diversity of existing opinions on any issue is recognized by him, whether he knows himself, whether he is prone to conflicts, how well his self-esteem is developed and respect for others, the ability to understand the other person, etc.

Dialogues, discussions, conversations, diagnostic methods, questionnaires, tests were used here. Such forms of educational activity make it possible to know our own deep personal essence, sometimes not always pleasant, stimulate self-interest, make it possible to express our feelings, realize our beliefs and values, and encourage us to work on ourselves [Lektorsky, 1997, p. 14-18].

Each stage of the technology involves the use of some experimental techniques. The communicative - emotional criterion of the formation of the culture of tolerance was tested using the communicative tolerance test of V. Boiko [Schekoldina, 2004; Bojko, 1996]. The test reveals the degree of tolerance or intolerance attitude towards others. In addition, the test makes it possible to determine tolerance or intolerance by some behavioral characteristics: understanding of the individuality of the others, tolerance (intolerance) to certain personal characteristics, emotional stability, conservatism and categoricity in evaluating other people, the ability to behave oneself when confront with non-communicative qualities of partners, the desire to change others, inability to forgive mistakes, adaptability to the characters and habits of others, intolerance to physical and mental discomfort. It should be noted that the results allow us to notice only the main trends and require our own analysis and understanding that can be done independently or during discussion or conversation in the supervised group. 
Education in the spirit of tolerance is not limited to the study and adoption of the concepts of «tolerance» and «tolerant person». Empathy, imagination, sympathy reveal the essence of differences from others. Therefore, the second test of examination of the communicativeemotional criterion was the diagnostic method, reflecting the degree of empathic ability, the author of the method V. Buteiko [Schekoldina, 2004]. The group was offered a list of questions that had to be answered «yes» or «no», then the number of answers matched with the key answers was calculated to get the total score. After testing you can discuss the results, analyze them in a group or singly.

The technology of forming the culture of tolerance in students in the activities of the mentor of the students' group

1. Planning and modeling phase

Stage goal Organization of diagnosing the degree of manifestation of tolerance in students, actualization of the ideological (axiological) attitudes of students.

Stage con- Actualization of the ideological (axiological) attitudes of students, the formation of skills of tent self-analysis, the need to understand one's personality, the establishment of trusting relations.

Mentor's - Studying the axiological world of the students of the group;

Actions - Organization of dialogues, curatorial lessons in order to determine their own ideological attitudes;

- Organization of reflexive techniques.

Students' - Studying by students of their personal characteristics;

activities - Participation in discussions, dialogues, curatorial lessons in order to determine their ideological (value) attitudes, understanding of their personality;

- Participation in reflexive techniques for the purpose of introspection.

Field of in- Joint activities (teamwork) to develop self-interest, raising the level of general culture. teraction

Result of The transition from the actualization of ideological (axiological) attitudes to the willingness interaction of development the culture of tolerance, awareness of the priority of tolerance value, philosophical and ethical values of non-violence.

\section{Procedural and organizing phase}

Stage goal The development of interest in the personality of the Different, in the diversity of the world, in various points of view; development of methods of forming the culture of tolerance in students.

Stage con- The development of interest in the personality of the Different, in the diversity of the tent world, in various points of view; the formation of self-esteem and respect for the achievements of others; development of the mechanism of tolerance, development of communication skills, strengthening public and social ties.

Mentor's - Creating of tolerant-oriented environment; introduction of students in the system of $\operatorname{cog}$ Actions nition at the group level;

- Accustom to the values of tolerance through the organization of conversations about cultural diversity; the organization of excursions in neighboring countries; the organization of Christmas balls (Catholic Christmas) and Easter with foreigners and other events;

- Organization of training of tolerance, discussions, dialogue forms of communication, methods aimed at developing interest in own personality and the other;

- Organization of reflexive techniques. 
Students' $\quad$ Entering to the system of knowledge at the group level;

activities - Introduction to the values of tolerance through educational activities organized by the group's mentor;

- Participation in tolerance training exercises, discussions, dialogue forms of communication, techniques aimed at developing interest in one's own personality and the personality of others, developing the mechanism of tolerance;

- Participation in reflexive techniques for the purpose of self-examination.

Field of in- Joint activities (teamwork) to develop interest in the Different, in the personality of the Difteraction ferent; joint organization of events dedicated to the formation of the culture of tolerance; joint preparation of trainings of tolerance, discussions, dialogue forms of communication.

Result of Transition from the willingness of forming the culture of tolerance in students to integratinteraction ing experience and introducing principles of tolerance into professional and social activities.

\section{Result and analytical phase}

Stage goal Individual correlation of each student with tolerant attitudes, practicing the principles of tolerance.

Stage con- Application of developed methods in practice; self-analysis and reflection based on one's tent own value orientations, beliefs, attitudes.

Mentor's - Attraction of foreign lecturers; organizing meetings with foreign students, representatives Actions of various nationalities of the Russian Federation; the organization of Christmas balls (Catholic Christmas) and Easter with foreigners and other events;

- Organization of training lessons, role-playing games aimed at integrating of existing tolerant views, ideas, experience and putting them into practice;

- Organization of reflexive techniques;

- Analysis of intolerant personality manifestations and their correction.

Students' Participation in activities that contribute to the consolidation of tolerant behavioral attiactivities tudes in the university and outside the university;

- Participation in training lessons, role-playing games aimed at integrating existing tolerant views, ideas, experience and putting them into practice;

- Participation in reflexive techniques for the purpose of self-examination;

- Analysis of intolerant personality manifestations and their correction.

Field of in- Joint modeling of the culture of tolerant behavior on the basis of acquired knowledge, teraction skills, abilities, experience and personal tolerant attitudes and ideological orientations.

Result of Implementation of the formed attitudes of culture of tolerance in practice, in professional interaction and social activities.

The activity-creative criterion of the formation of the culture of tolerance was tested with the help of the K. Thomas test [Perepelitsyna, 2003; Perepelitsyna, 2004]. The test gives an opportunity to determine the prevalence of personal behavioral strategies, such as rivalry, cooperation, compromise, the desire for dialogue, avoidance, adaptation.

At the planning and modeling phase, it is very important to awake students' interest in the problems of the culture of tolerance itself. With this purpose in mind, curatorial lessons were organized with the themes of tolerance: «I, We and the Different», «Various Others», «Allow Different to be Different», «Who Are They? », «We and They: A Step to Meet». In the classroom, materials of «Gratis» Center of Tolerance and Humanitarian Technologies adapted for the mentors of the students' groups were used [Centr Tolerantnosti i Gumanitarnyh Tehnologij «Gratis», 2013].

At the first phase, it is very important to give students the opportunity to «open up», not to be afraid to express their thoughts and feelings, to encourage them to express their opinions openly. The task of the mentor at this stage was to support and assist students, ensuring their 
psychological security and freedom. The oral commentary of the mentor is able to help, encourage, and control the emotions of the pupils. It is important the promotion of students' success. During curatorial lessons, testing, conversations, discussions, the mentor monitored the course of work, answered questions, entered into dialogue, expressing his own opinion and summing up the discussion [Avery Patricia G., 2002, p. 270-275].

The result of interaction of the mentor and the students' group at the first stage is the transition from the actualization of ideological (axiological) attitudes and awareness of the priority of tolerance value, philosophical and ethical values of non-violence to the willingness of development the culture of tolerance.

During the planning and modeling phase, the following pedagogical condition was implemented: ensuring the unity of the theoretical and technological training of mentors to formation of the culture of tolerance in students («School for the mentor of the students' group»), which contributed to the realization of the following condition: systematic educational activities of the mentor of students' group on formation of the culture of tolerance in students in the educational process of the educational institution (school).

Readiness for the formation of the culture of tolerance, the development of interest in the personality of the Different, the diversity of the world, different points of view, as well as the development of methods of the forming of the culture of tolerance by students have become the goal of the second stage - procedural and organizing phase.

At this stage, the mentor of the student group becomes the organizer, participant and coordinator of joint activities.

The development of interest in the personality of the Different, in the diversity of the world, in various points of view; the formation of self-esteem and respect for the achievements of others; development of the mechanism of tolerance, development of communication skills, strengthening public and social ties is the content of the educational activities of the phase [Bless N., 1994, pp. 11-18; Brunel Jerome S., 1999].

The functions of the mentor at this stage are to create a tolerant-oriented environment, which allows students to join the system of knowledge at the group level, and then at the individual level [Wan Guofang, 2006, p. 140-144].

The organization of tolerance training lessons, discussions, dialogue forms of communication, methods aimed at the developing of the interest in one's own personality and the other's personality are the most important components at this stage.

Important educational tools that promote the formation of the culture of tolerance are, in our opinion, psychological and pedagogical trainings that are conducted in tolerant-oriented educational environment. Group trainings are the most appropriate form of work, interesting for students and allowing them to integrate the norms and principles of the culture of peace in an accessible form.

In the training situation, the role of the teacher-mentor changes, who helps during the training each participant determine the criteria and system of his assessment, understand himself/herself, understand and accept the Different, control his/her thoughts and actions [Isaev et al., 2009, p. 276; Isaev, Eroshenkova, 2010].

In order to form the culture of tolerance in students, we have developed training of tolerance. The "Training of Tolerance» by S. D. Schekoldina is taken as the base [Schekoldina, 2004]. In addition, the materials of «Gratis» Center of Tolerance and Humanitarian Technologies [Centr Tolerantnosti i Gumanitarnyh Tehnologij «Gratis»] were used in the classroom at the lessons. The founders of the Center G. Soldatova, O. Kravtsova, L. Shaigerova note that tolerance trainings is widely used in many regions of Russia, including the regions and republics with high interethnic tension and instability. Any developed training can be modified independently, besides it is necessary to take into account the national and cultural characteristics of its participants. The mentors of students' groups, teachers can use separate exercises and classes in the structure of the curatorial lesson. It should be particularly noted that trainings of tolerance are applicable to groups of different sizes and can be applied in different conditions. Conducting 
training lessons, it is desirable to take into account: the psychological and pedagogical age characteristics of the participants, their cultural identity and religion [Soldatova i dr., 2000].

The training consists of 10 sessions, which are held once a week for 1 hour. The developed group tolerance training covers the following issues:

- concepts of tolerance and intolerance;

- «limits» of tolerance;

- reveals the features of tolerant and intolerant personality;

- introduces the concept of «tolerant communication»;

- forms the tolerant attitude towards oneself, self-esteem and ability to self-knowledge;

- forms the culture of peace through the phenomenon of tolerance;

- allows you to determine the degree of tolerance;

- allows you to learn to understand the emotional state of others, as well as manage your emotions;

- forms the skills of conflict-free interaction and positive attitude to the problem situation.

As mentioned earlier, the number of training lessons depends on the level of tolerance in the group. Some groups will need a full course of study, others will need a few classes, and groups with a quite high level of tolerance will need only 1-2 classes per semester or year.

The best option is if the mentor participates in the group training as an ordinary member of the group, while at the same time monitoring the progress of the work.

In addition to training lessons, the introduction of tolerance values is possible through the organization of conversations about cultural diversity, the organization of excursions in neighboring countries, the organization of Christmas balls (Catholic Christmas) and Easter with foreigners, and other events.

At this stage, the mentors used the following topics of conversations: «The modern world, what is it?», «Tales and myths of the peoples of the world», «World religions», «Traditions and customs of the peoples of the world», etc.

In addition to conversations and meetings, at this stage there were sports competitions in volleyball, basketball, football, table tennis, chess, etc., with the participation of foreign students. This also true of labor matters [Uolcer, 2000].

The purpose of the techniques carried out in the experimental groups at this phase was developing interest in the personality of the Different, the diversity of the world, different points of view, and also including in the organization of events that promote the formation of the culture of tolerance.

The result of interaction at the procedural and organizing phase is the transition from the willingness of forming the culture of tolerance to integrating experience and introducing principles of tolerance into professional and social activities.

At this stage, the following pedagogical conditions were implemented: systematic educational activities of the mentor of students' group on formation of the culture of tolerance in the educational process of the educational institution and the establishment of tolerance-oriented educational environment in the students' group.

The third stage in the formation of the culture of tolerance - result and analytical phase set as its goal the individual correlation of each student with tolerant attitudes and practicing the principles of tolerance.

The interaction of the mentor and the students at this phase consists in applying of developed methods in practice, conducting of self-analysis and reflection on the basis of their own value orientations, beliefs and attitudes. Joint efforts of both parties are aimed at modeling the culture of tolerant behavior based on the gained knowledge, skills, abilities, experience and personal tolerant attitudes and value orientation. 
At this stage, it was implemented such pedagogical condition as the subject-subjectival interaction of the mentor and students. The important goal of the mentor was the organization of training lessons, role-playing games aimed at integrating of existing tolerant views, ideas, experience and putting them into practice, as well as analyzing of intolerant personality manifestations and their correction.

Training sessions were used for consolidation of tolerant behavioral attitudes. And for this purpose curatorial hours with the theme of tolerance, meetings with foreign students and representatives of various nationalities were arranged, foreign lecturers were involved into the teaching process, Christmas balls (Catholic Christmas) and Easter with foreigners were organized, etc.

At the last lesson, the questionnaire survey was conducted, where students independently determined the degree of their activity in the course of classes, wrote wishes to the mentor, defined the degree of manifestation of their tolerance (high, middle, low), and noted what purposes tolerance helps to achieve.

\section{Conclusions}

The techniques and technologies of the last stage (result and analytical phase) contributed to the realization of the formed attitudes of culture of tolerance in students in practice, in professional and social activities. A joint modeling of culture of tolerant behavior was carried out on the basis of the knowledge, skills, abilities, experience and personal tolerant attitudes and value orientations obtained.

At this stage, the analysis and correction of intolerant personality manifestations were carried out on the basis of expert evaluation. Using the data and information obtained, the activities of the groups participating in the experiment were regulated and managed. The pedagogical conditions identified earlier are: 1) systematic educational activities of the mentor of students' groups on formation of the culture of tolerance in students in the educational process of the educational institution; 2) ensuring the unity of the theoretical and technological training of mentors to formation of the culture of tolerance in students; 3) the establishment of tolerance-oriented educational environment in the students' group; 4) the subject-subjectival interaction of the mentor and students. These pedagogical conditions were implemented in the technology of forming the culture of tolerance of students in educational activities, consisting of three stages.

\section{Список литературы References}

1. Бойко В.В. 1996. Энергия эмоций в общении: взгляд на себя и других. М., Информационно-издательский дом «Филинь», 472.

Bojko V.V. 1996. Jenergija jemocij v obshhenii: vzgljad na sebja i drugih [The energy of emotions in communication: a look at themselves and others]. Moscow, Informacionno-izdatel'skij dom «Filin'», 472.

2. Бондаревская Е.В. 2010. Феноменологический анализ современных концепций воспитания. URL: htth: //www.auditorium.ru/conf/data/3410/bondarevskaja.doc (дата обращения: 14 января 2019).

Bondarevskaja E.V. 2010. Fenomenologicheskij analiz sovremennyh koncepcij vospitanija. [Phenomenological analysis of modern concepts of education]. Available at: htth: //www.auditorium.ru/conf/data/3410/bondarevskaja.doc (accessed 14 January 2019).

3. Исаев И.Ф., Ерошенкова Е.И., Кролевецкая Е.Н. 2009. Куратору студенческой группы: от теории к практике. Белгород, Изд-во БелГУ, 350.

Isaev I.F., Eroshenkova E.I., Krolevetskaya E.N. 2009. Kuratoru studencheskoj gruppy: ot teorii k praktike [To the mentor of the student group: from theory to practice]. Belgorod, Izd-vo BelGU, 350. 
4. Исаев И.Ф., Ерошенкова Е.И. 2010. Моделирование процесса формирования профессионально-ценностной установки будущего специалиста в вузе. Высшее образование сегодня, 6: 68-70.

Isaev I.F., Eroshenkova E.I. Modelirovanie protsessa formirovaniya professional'no-tsennostnoy ustanovki budushchego spetsialista $\mathrm{v}$ vuze [Simulation of the formation of the professional value unit of the future specialist in high school]. Vysshee obrazovanie segodnya, 6: 68-70.

5. Исаев И.Ф., Ерошенкова Е.И. 2010. Профессионально-ценностная установка: диалог куратора и студента. Белгород, Изд-во БелГУ, 202.

Isaev I.F., Eroshenkova E.I. 2010. Professional'no-cennostnaja ustanovka: dialog kuratora i studenta [Professional value setting: the dialogue of the mentor and the student]. Belgorod, Izd-vo BelGU, 202.

6. Колеченко А.К. 2006. Энциклопедия педагогических технологий. Спб., КАРО, 368.

Kolechenko A.K. 2006. Jenciklopedija pedagogicheskih tehnologij [Encyclopedia of educational technology]. St. Petersburg, KARO, 368.

7. Лекторский В.А. 1997. О толерантности. Философские науки, 3-4: 14-18.

Lektorsky V.A. 1997. O tolerantnos [About Tolerance]. Filosofskie nauki, 3-4: 14-18.

8. Перепелицына М.А. 2003. Уровни сформированности толерантности как качества личности будущего учителя. Волгоград, Перемена, 136.

Perepelitsyna M.A 2003. Urovni sformirovannosti tolerantnosti kak kachestva lichnosti budushchego uchitelya [Levels of formation of tolerance as a quality of personality of the future teacher]. Volgograd, Interval, 136.

9. Перепелицына М.А. 2003. Формирование толерантности в педагогическом образовании. В кн.: Развитие личности в образовательных системах Южно-Российского региона. Ростов н/Д, Издательство РГПУ, Часть II: 33-34.

Perepelitsyna M.A. 2003. Formation of tolerance in pedagogical education. In: Personality development in educational systems of the South-Russian region [Personality development in educational systems of the South-Russian region]. Rostov on Don, Press of RGPU, Part II: 33-34.

10. Перепилицина М.А. 2004. Формирование педагогической толерантности у будущих учителей. Дис. ...канд. пед. наук. Волгоград, 158 с.

Perepilicina M.A. 2004. Formirovanie pedagogicheskoj tolerantnosti u budushhih uchitelej [Formation of pedagogical tolerance in future teachers]. Dis. ... cand. ped. sciences. Volgograd, $158 \mathrm{p}$.

11. Потапенко А.В. 2016. Межэтническая толерантность как социальная ценность. Концепт, 27: 57-65. URL: http://e-koncept.ru/2016/56449.htm. (дата обращения: 15 ноября 2018).

Potapenko A.V. 2016. Mezhjetnicheskaja tolerantnost' kak social'naja cennost' [Ethnic tolerance as social value]. Koncept, 27: 57-65. Available at: http://e-koncept.ru/2016/56449.htm.] (accessed 15 November 2018).

12. Селевко Г.К. 2005. Альтернативные педагогические технологии. Серия «Энциклопедия образовательных технологий». М., НИИ шк. техн., 224.

Selevko G.K. 2005. Al'ternativnye pedagogicheskie tehnologii [Alternative pedagogical technologies]. Serija «Jenciklopedija obrazovatel'nyh tehnologij». Moscow, Research sch. tech., 224.

13. Селевко Г.К. 2005. Педагогические технологии на основе дидактического и методического усовершенствования УВП. Серия «Энциклопедия образовательных технологий». М., НИИ шк. техн., 288.

Selevko G.K. 2005. Pedagogicheskie tehnologii na osnove didakticheskogo i metodicheskogo usovershenstvovanija UVP [Pedagogical technologies based on didactic and methodological improvement of EP]. Serija «Jenciklopedija obrazovatel'nyh tehnologij». Moscow, Research sch. tech., 288.

14. Солдатова Г.У., Шайгерова Л.А., Шарова О.Д. 2000. Жить в мире с собой и другими: тренинг толерантности для подростков. М., Генезис, 112.

Soldatova G.U., Shaygerova L.A., Sharova O.D. 2000. Zhit' v mire s soboj i drugimi: trening tolerantnosti dlja podrostkov [Living in peace with yourself and others: tolerance training for teenagers]. Moscow, Genezis, 112.

15. Уолцер М. 2000. О терпимости: пер. с англ. М., Идея. Пресс. Дом интеллектуальной книги, 160. 
Uolcer M. 2000. O terpimosti: per. s angl. [About tolerance]. Moscow, Ideja. Press. Dom intellektual'noj knigi, 160.

16. Центр Толерантности и Гуманитарных Технологий «Гратис». 2013. URL: http://www.gratis.su/hum_tech/grouptrain.shtml (дата обращения: 15 мая 2017).

Centr Tolerantnosti i Gumanitarnyh Tehnologij «Gratis». 2013. [Center of Tolerance and Humanitarian Technologies «Gratis»]. Available at: http://www.gratis.su/hum_tech/grouptrain.shtml (accessed 15 May 2017).

17. Щеколдина С.Д. 2004. Тренинг толерантности. М., «Ось-89», 80.

Schekoldina S.D. 2004. Trening tolerantnosti [Tolerance training]. Moscow, «Os'-89», 80.

18. Avery P.G. 2002. Teaching Tolerance: What Research Tells Us (Research and Practice). Social Education, 66(5): 270-275.

19. Bless N. 1994. Teaching Tolerance. Afterimage, 22(2): 11-18.

20. Brunel Jerome S. 1999. The Process of Education. A Landmark in Educational Theory. Harvard University Press, Cambridge, Massachusetts, London, England.

21. Verbitskaya S.A. 2019. The model of education for developing the culture of tolerance in future specialists in the university environment. Research Results. Pedagogy and Psychology of Education, 5(1): 41-49, DOI: 10.18413/2313-8971-2019-5-1-0-3.

22. Wan Guofang 2006. Teaching Diversity and Tolerance in the Classroom: A Thematic Storybook Approach. Education, 127 (1): 140-144.

\section{Ссылка для цитирования статьи Reference to article}

Вербицкая С.А., Анохина С.В. Технология формирования культуры толерантности в образовательных организациях среднего профессионального и высшего образования Научные ведомости Белгородского государственного университета. Серия: Гуманитарные науки, 38 (3): 428-438. DOI: 10.18413/2075-4574-2019-38-3-428-438

Verbitskaya S.A., Anokhina S.V. Technology of forming the culture of tolerance in educational institutions of secondary vocational and higher education Belgorod State University Scientific Bulletin. Humanities series, 38 (3): 428-438 (in Russian). DOI: 10.18413/2075-4574-2019-38-3-428-438 